\title{
Detection of HPV-16 DNA by PCR in histologically cancer free lymph nodes from patients with cervical cancer
}

M F D Baay, J Koudstaal, H Hollema, J M Duk, M P M Burger, W G V Quint, E Stolz, P Herbrink

\begin{abstract}
The prognostic value of detection of human papillomavirus (HPV) type 16 DNA in histologically cancer free lymph nodes was assessed in left obturator lymph nodes from cervical cancer patients with HPV-16 positive primary tumours. HPV-16 DNA was detected by polymerase chain reaction in 12 of 35 patients with histologically cancer free lymph nodes. Of these 12 patients, only one developed a recurrence, suggesting HPV-16 DNA detection in cancer free lymph nodes has no prognostic value.

(F Clin Pathol 1997;50:960-961)
\end{abstract}

Dermatovenereology,

Erasmus University

Rotterdam,

Netherlands

M F D Baay

E Stolz

Department of

Pathology, University

Hospital Groningen,

Netherlands

J Koudstaal

H Hollema

Department of

Obstetrics and

Gynaecology

J M Duk

Division of Obstetrics and Gynaecology, Academic Medical

Center, University of

Amsterdam,

Netherlands

M P M Burger

Department of

Molecular Biology,

Diagnostic Centre

SSDZ, Delft,

Netherlands

W G V Quint

Department of Immunology and Infectious Diseases P Herbrink

Correspondence to: Dr Herbrink, Department of Immunology and Infectious Diseases, Diagnostic Centre SSDZ, PO Box 5010, 2500 GA Delft, Netherlands.

Accepted for publication 28 July 1997
Keywords: human papillomavirus; cervical cancer; lymph nodes; prognosis; polymerase chain reaction

The association between the presence of human papillomavirus (HPV) DNA and cervical carcinoma has been established beyond doubt. ${ }^{1}$ Presence or absence of pelvic lymph node involvement is one of the strongest predictive factors for prognosis in patients with cervical cancer. ${ }^{2} \mathrm{~A}$ number of studies has investigated the presence of HPV DNA in lymph nodes from patients with HPV DNA in their primary tumour $^{3-5}$ and found HPV DNA positivity ranging from $14.3-50 \%$ in histologically negative lymph nodes. However, the prognostic significance could not be established in these reports because of lack of follow up data.

\section{Methods}

To investigate the frequency of detectable HPV DNA in histologically cancer free lymph nodes, we examined 50 patients with squamous cell cervical carcinoma treated at the department of obstetrics and gynaecology, University Hospital Groningen (median time of follow up was 47.5 months; range 24-132 to the FIGO classification as stage $\mathrm{Ib}(\mathrm{n}=36)$, stage IIa $(n=9)$, or stage IIb $(n=5)$. All patients were positive for HPV type 16 in their primary tumour. From these patients paraffin wax embedded tissue of the left obturator lymph nodes (one node for each patient) was investigated. (We do not think that analysis of a single obturator lymph node would introduce bias.) All 50 obturator lymph nodes examined were histologically negative for tumour cells. However, 15 patients had histological evidence of metastasis to one or more other lymph nodes. months). The patients were staged according
DNA was extracted from $10 \mu \mathrm{m}$ sections by deparaffination and digestion with proteinase $\mathrm{K}$ as described by Wright and Manos. ${ }^{6}$ Adjacent sections were stained with haematoxylin and eosin. As a control for DNA extraction $\beta$ globin primers PC03/04 (ACACAACTGTGTTCACTAGC and CAACTTCATCCACGTTCACC) were used. For detection of HPV-16 DNA a primer pair (GGTCGGTGGACCGGTCGATG and GCAATGTAGGTGTATCTCCA) described in Baay et al, ${ }^{7}$ spanning a 96 base pair DNA sequence of the E6 open reading frame was used.

Polymerase chain reaction (PCR) amplification was performed according to the method of Saiki et al. ${ }^{8}$ The final $100 \mu \mathrm{l}$ PCR reaction contained $10 \mu$ sample, $10 \mathrm{mM}$ Tris- $\mathrm{HCl} \mathrm{pH}$ 9.0, $50 \mathrm{mM} \mathrm{KCl}, 2.5 \mathrm{mM} \mathrm{MgCl}_{2}, 0.1 \%$ Triton $\mathrm{X} 100,0.01 \%$ gelatin, $200 \mu \mathrm{M}$ dNTPs, $50 \mathrm{pmol}$ of each primer, and 0.25 units of SuperTaq (Sphaero Q, Cambridge, UK). Standard PCR conditions were one minute at $95^{\circ} \mathrm{C}$, one minute at $52^{\circ} \mathrm{C}$, and two minutes at $72^{\circ} \mathrm{C}$, for 40 cycles. After PCR, $15 \mu \mathrm{l}$ of all samples were run on a $2 \%$ agarose gel, gels were blotted (Hybond $\mathrm{N}^{+}$; Amersham, Little Chalfont, UK) and hybridised with random labelled HPV-16 E6. Blots were washed twice for 15 minutes in $2 \times$ SSC, $0.1 \%$ SDS at $42^{\circ} \mathrm{C}$.

\section{Results}

All obturator lymph nodes were positive in the $\beta$ globin PCR (100 base pair DNA fragment). Nineteen $(38 \%)$ of the obturator lymph nodes were positive for HPV-16 DNA. HPV-16 DNA was detected in seven of 15 patients $(46.6 \%)$ with known lymph node involvement elsewhere, compared with 12 of 35 patients $(34.3 \%)$ without histological evidence for lymph node involvement. Therefore, no difference was found between these groups of patients with regard to the frequency of HPV-16 DNA $\left(p=0.61 ; \chi^{2}\right.$ test with Yates' correction). Furthermore, there was no significant difference in staging between patients with HPV positive cancer free lymph nodes (Ib, $n=10$, IIa, $n=2)$, and patients with HPV negative cancer free lymph nodes (Ib, $\mathrm{n}=19, \mathrm{II} a, \mathrm{n}=4)$.

\section{Discussion}

In approximately one-third (12 of 35$)$ of the patients without histological evidence for lymph node involvement, HPV-16 DNA could be detected in the lymph node examined. This is in accordance with data from the literature 
where HPV DNA positivity in histologically negative lymph nodes ranging from $14.3-50 \%$ has been reported. ${ }^{3-5}$

Burnett $e t$ al assign a prognostic value to the detection of HPV DNA in histologically negative lymph nodes. ${ }^{9}$ This assumption has been based on the finding that, in six patients with recurrent disease, 22 of 31 (71\%) histologically negative lymph nodes were positive for HPV DNA compared with 15 of 43 (35\%) histologically negative lymph nodes from six patients in complete remission. It is not clear, however, whether the number of HPV DNA positive nodes in the individual patient is related to clinical outcome. ${ }^{9}$ Nawa et al reported recurrence of disease in two of five patients with cancer free lymph nodes that were positive for HPV DNA. ${ }^{4}$ In the present study, only one of 12 patients without histological evidence for lymph node involvement but positive for HPV DNA developed a recurrence. All other patients showed no evidence of disease (median time of follow up, 47.5 months; range 24-132 months). This is in accordance with results of the study by Hording et al, ${ }^{10}$ which showed no correlation between HPV presence and recurrence.

In the study by Burnett et al, five of six patients with recurrence were positive for HPV-18. ${ }^{9}$ This HPV type has been described as biologically more aggressive than HPV-16. ${ }^{11}$ Therefore, it cannot be ruled out that detection of HPV-18 DNA in histologically negative lymph nodes may be of prognostic value. The presence of HPV DNA in histologically negative lymph nodes may be due to subclinical metastasis of tumour cells. Alternatively it may represent DNA from tumour cells destroyed by immune competent cells, either as circulating fragments or internalised by scavenger cells, such as macrophages. Possibly, detection of HPV specific mRNA might provide an answer to this question. Unfortunately, too little material was available to perform such an analysis in the present study.
In conclusion, no prognostic value has been found for the detection of HPV DNA in histologically cancer free lymph nodes from patients with HPV-16 positive primary tumours.

The authors thank Emma Marie Koch for excellent technical assistance.

1 Munoz N, Bosch FX, De Sanjose S, Tafur L, Izarzugaza I, Gili $M$, et al. The causal link between human papillomavirus and invasive cervical cancer: a population-based case-control study in Colombia and Spain. Int 7 Cancer 1992;52:743-9.

2 Van Bommel PF, van den Brule AJ, Helmerhorst TJ, Gallee MP, Gaarenstroom KN, Walboomers JM, et al. HPV DNA presence and HPV genotypes as prognostic factors in lowstage squamous cell cervical cancer. Gynecol Oncol 1993;48:333-7.

3 Fuchs PG, Girardi F, Pfister H. Human papillomavirus 16 DNA in cervical cancers and in lymph nodes of cervical cancer patients: a diagnostic marker for early metastases? Int 7 Cancer 1989;43:41-4.

4 Nawa A, Nishiyama Y, Kikkawa F, Kawai M, Mano H, Goto $\mathrm{S}$, et al. Detection of human papillomaviruses from histologically normal lymph nodes of Japanese cervical cancer patients by nested polymerase chain reaction assay. Int $\mathcal{F}$ Cancer 1993;53:932-7.

5 Claas ECJ, Melchers WJG, van der Linden HC, Lindeman J, Quint WGV. Human papillomavirus detection in paraffin-embedded cervical carcinomas and metastases of the carcinomas by the polymerase chain reaction. $\mathrm{Am} \mathcal{F}$ Pathol 1989;135:703-9.

6 Wright DK, Manos MM. Sample preparation from paraffin-embedded tissues. In: Innis MA, Gelfand DH, Sninsky JJ, eds. Polymerase chain reaction protocols: a guide to methods and applications. San Diego: Academic Press, 1990: 153-8.

7 Baay MFD, Quint WGV, Koudstaal J, Hollema H, Duk JM, Burger MPM, et al. A comprehensive study of several general and type-specific primer pairs for detection of human papillomavirus DNA by polymerase chain reaction in paraffin-embedded cervical carcinomas. $\exists$ Clin Microbiol paraffin-embedded

8 Saiki RK, Gelfand DH, Stoffel S, Scharf SJ, Higuchi R, Horn GT, et al. Primer-directed enzymatic amplification of DNA with a thermostable DNA polymerase. Science 1988; 239:487-91

9 Burnett AF, Barnes WA, Johnson JC, Grendys E, Willett GD, Barter JF, et al. Prognostic significance of polymerase chain reaction detected human papillomavirus of tumors and lymph nodes in surgically treated stage IB cervical and lymph nodes in surgically treated

10 Hording U, Ravn V, Knudsen J, Visfeldt J. The use of polymerase chain reaction to detect metastatic cancer cells within lymph nodes in stage I cervical carcinoma. Int $\mathcal{F}$ Gynecol Pathol 1995;14:339-43.

11 Barnes W, Woodworth G, Waggoner S, Stoler M, Jenson $A B$, Delgado $G$, et al. Rapid dysplastic transformation of human genital cells by human papillomavirus type 18 . Gynecol Oncol 1990;38:343-6. 